\author{
PENDIDIKAN MASA DAULAH GAZNAWIYAH, \\ BUWAIKHI, DAN SALAJIKAH \\ (Perkembangan dan Tokoh-tokohnya) \\ Oleh : Norliani, S.Pd.I
}

(Pengajar Sejarah Kebudayaan Islam Pada MA Darul Ilmi Banjarbaru Kalsel, norliani.mtp@gmail.com

\begin{abstract}
Abstrak
Di dalam sejarah peradaban Islam, pembangunan bidang pendidikan mendapat perhatian yang sangat besar oleh penguasa dari berbagai daulah, tidak terkecuali pada masa daulah Gaznawiyah, Buwaikhi dan Salajikah. Meskipun ketiga daulah ini disebutkan berada pada fase kemunduran peradaban Islam itu sendiri, namun perhatian penguasa terhadap bidang pendidikan tidak berkurang, bahkan tetap berkembang cukup pesat. Materi sejarah yang mengungkapkan jejak-jejak peradaban di bidang pendidikan pada masa tiga daulah tersebut sangat terbatas dan perlu dilakukan eksplorasi data kesejarahan sehingga dapat disajikan dalam pembelajaran Sejarah Kebudayaan Islam. Melalui studi pustaka dengan pendekatan sosio historis, ditemukan fakta-fakta sejarah tentang perkembangan pendidikan pada masa daulah Gaznawiyah, Buwaikhi dan Salajikah, yaitu: (1) politik kekuasaan yang diterapkan oleh ketiga daulah tersebut mempengaruhi model lembaga pendidikan yang berkembang seperti terbentuknya sekolah-sekolah yang berorientasi kemazhaban maupun paham tertentu, dan semua itu tidak terlepas dari aliran atau paham yang dianut oleh sang penguasa seperti pada masa daulah Gaznawiyah dan Buwaikhi dengan paham syi'i. (2) Meskipun pengaruh paham aliran maupun paham mazhab sedemikian kuat dalam pembentukan lembaga pendidikan, namun model madrasah yang dikembangkan oleh Nizam al-Mulk pada masa Daulah Salajikah memberikan kontribusi yang besar pada perkembangan pendidikan masa selanjutnya terutama pembangunan Lembaga Perguruan Tinggi Islam; dan (3) Tokoh-tokoh yang menopang terselenggaranya pendidikan pada masa Dualah Gaznawiyah, Buwaikhi dan Salajikah adalah para penguasa dan para ulama/cendekiawan muslim. Sebagian besar dari tokoh-tokoh tersebut merupakan alumni dari lembaga-lembaga pendidikan yang berkembang pada masa dualah tersebut.
\end{abstract}

Kata Kunci : Materi Sejarah, Daulah, Politik Kekuasaan, Lembaga Pendidikan

\title{
PENDAHULUAN
}

Informasi kesejarahan tentang perkembangan pendidikan di masa daulah Gaznawiyah, Buwaikhi dan Salajikah begitu terbatas. Padahal di tiga masa daulah tersebut merupakan bagian yang inheren atau tidak bisa dipisahkan dari rantai perkembangan pendidikan di dunia Islam yang dimulai dari masa kenabian Nabi Muhammad SAW sampai pada masa kekuasaan daulah, terutama pada masa daulah Abbassiyah.

Al Qalam: Jurnal Ilmiah Keagamaan dan Kemasyarakatan Vol. 16, No. 2

Maret - April 2022 
Norliani : Pendidikan Masa Daulah Gaznawiyah, Buwaikhi, dan Salajikah (Perkembangan dan Tokohnya)

Di masa keemasan Daulah Abbassiyah--terutama pada pemerintah-an khalifah Harun arRasyid, al-Makmun, dan al-Mutawakkil-ilmu pengetahuan berkembang dengan pesat. Perkembangan yang sedemikian pesat tersebut tidak terlepas dari peran pendidikan yang mentransformasi ilmu pengetahuan Yunani dan Persia ke dalam kebudayaan umat Islam saat itu. ${ }^{1}$ Upaya pendidikan itu sendiri dipelopori oleh penguasa dan didukung oleh masyarakat sehingga perkembangan ilmu pengetahuan menjadi pemicu kemajuan di bidang kehidupan lainnya, seperti teknologi, ekonomi, sosial budaya, seni dan politik pemerintahan.

Upaya pendidikan yang dilakukan antara lain penyelenggaran pendidikan di Kuttab, Mesjid, Istana, dan Perpustakaan. Kemudian upaya penterjemahan buku-buku Yunani dan Persia ke dalam bahasa Arab, serta lahirnya sejumlah tokoh cendekiawan yang menulis sejumlah karya tulis dengan pembahasan aspek ilmu tertentu seperti Agama, filsafat, astronomi, kedokteran, hukum, dan seterusnya.

Pada saat Daulah Abbassiyah mengalami kemunduran--terutama dalam bidang politik--, beberapa wilayah kekuasaannya memisahkan diri dan membentuk daulah tersendiri. Walaupun demikian, daulah-daulah yang terbentuk masih memiliki hubungan spiritual ${ }^{2}$ dengan pemerintahan Daulah Abbassiyah yang berpusat di Baghdad. Hubungan tersebut diperlukan dalam rangka legitimasi kekuasaan daulahnya di bekas wilayah kekuasaan Daulah Abbassiyah, sehingga eksistensinya semakin mantap dengan mendapat dukungan penuh dari rakyatnya. Disamping itu, tentu saja pemberian legitimasi tersebut memiliki visi strategis untuk mempertahankan pengaruh Daulah Abbasiyah yang mulai pudar seiring melemahnya pemerintahan dan kekuatan militer. ${ }^{3}$

Meskipun Daulah Abbassiyah mengalami kemunduran, upaya pendidikan tersebut masih berlanjut pada masa daulah-daulah tersebut antara lain yang terjadi pada masa pemerintahan daulah Buwaikhi, Gaznawiyah, dan Salajikah. Hal ini dapat dilihat lahirnya madrasah sebagai bentuk baru dari lembaga pendidikan sebelumnya. Disamping itu, perkembangan pendidikan juga ditandai dengan kehadiran sejumlah tokoh cendekiawan dengan disiplin ilmu pengetahuan masing-masing.

\footnotetext{
${ }^{1}$ Harun Nasution, Filsafat Dan Mistisisme Dalam Islam, 8th ed. (Jakarta: Bulan Bintang, 1992), 11.

Pendapat yang lain mengungkapkan dengan istilah pengakuan nominal dari propinsi-propinsi tertentu, dengan pembayaran upeti Hal ini dilakukan karena kemungkinan para khalifah tidak cukup kuat untuk membuat mereka tunduk kepadanya, dan penguasa Bani Abbas lebih menitikberatkan pembinaan peradaban dan kebudayaan daripada politik dan ekspansi. Badri Yatim, Sejarah Peradaban Islam, 2nd ed. (Jakarta: PT RajaGrafindo Persada, 1994), 63; W. Montgomery Watt, Politik Islam Dalam Lintasan Sejarah (Jakarta: P3M, 1988), 152.

${ }^{3}$ Hasan Ibrahim Hasan, Islamic History and Culture, trans. Djahdan Umam, 1st ed. (Yogyakarta: Kota Kembang, 1989), 209.
}

Al Qalam: Jurnal Ilmiah Keagamaan dan Kemasyarakatan Vol. 16, No. 2

Maret - April 2022 
Norliani : Pendidikan Masa Daulah Gaznawiyah, Buwaikhi, dan Salajikah (Perkembangan dan Tokohnya)

Dalam rangka mengeksplorasi topik ini lebih mendalam yakni tentang pendidikan masa Dualah Buwaikhi, Gaznawiyah, dan Salajikah, penulis merumuskan permasalahan seputar topik tersebut sebagai berikut:

1. Bagaimana perkembangan pendidikan pada masa Dualah Buwaikhi, Gaznawiyah, dan Salajikah?

2. Siapa saja tokoh-tokoh yang muncul pada masa Dualah Buwaikhi, Gaznawiyah, dan Salajikah?

Terhadap pembahasan atas rumusan permasalahan ke-2, penulis menegaskan bahwa yang dimaksud dengan 'tokoh' adalah mereka yang terlibat langsung dalam penyelenggaraan pendidikan pada masa dualah tersebut, seperti para penguasa dan para ulama/cendekiawan muslim.

\section{METODE PENULISAN}

Eksplorasi data kesejarahan dari perkembangan pendidikan di masa Daulah Gaznawi, Buwakhi dan Salajikah dilakukan dengan studi literatur sejarah, terutama literatur sejarah kebudayaan atau peradaban Islam. Dalam pembahasannya, penulis menggunakan pendekatan sosio historis yaitu sebuah upaya penulis untuk menggali latar sosial yang berperan dalam perkembangan pendidikan pada masa ketiga daulah tersebut.

\section{PEMBAHASAN}

\section{A. Perkembangan Pendidikan pada Masa Daulah Gaznawiyah}

Daulah ini terbentuk pada tahun 366 H / 976 M dan berakhir pada tahun 579 H / 1183 M. Dibangun oleh Sebuktigin (336-387 H / 976-997 M), berpusat di Ghazna. ${ }^{4}$ Daulah ini mencapai puncak kejayaannya pada masa pemerintahan Mahmud ibn Sebuktigin (387-421 H / 997-1030 M), sehingga dia juga dikenal dengan sebutan Mahmud al-Ghaznawi. Tokoh ini merupakan tokoh terbesar dari Dinasti Ghazna. ${ }^{5}$

Pada masa pemerintahan Mahmud, Ghazna menjadi pusat tradisi Persia dan mengulang masa keemasan Sasanian. Mahmud memberikan perlindungan dan apresiasi kepada para ilmuan dan seniman dengan cara memberikan honor atas karya yang dibuatnya. Karena itu, dalam masanya, bidang kebudayaan dan ilmu pengetahuan mengalami kemajuan. Misalnya Kitab Shah-Namah (Kitab Raja-raja) yang berbentuk epos (syair-syair kepahlawanan pada masa Kerajaan Iran Purba),

\footnotetext{
${ }^{4}$ Lihat Joesouf Sou'yb, Sejarah Daulat Abbassiyah (Jakarta: Bulan Bintang, 1977), 54.

${ }^{5}$ Lihat C. Brockelmann, History of Islamic Peoples (London: Routledge and Kegan Paul, 1980),
} 168.

$$
\begin{gathered}
\text { Al Qalam: Jurnal Ilmiah Keagamaan dan Kemasyarakatan Vol. 16, No. } 2 \\
\text { Maret - April } 2022
\end{gathered}
$$


Norliani : Pendidikan Masa Daulah Gaznawiyah, Buwaikhi, dan Salajikah (Perkembangan dan Tokohnya)

ditulis oleh Firdawsi dalam bahasa Persia; Kitab Sejarah tentang India oleh Abu Raihan al-Biruni (wafat $1048 \mathrm{M}){ }^{6}$

Disamping itu keduanya adalah sarjana atau orang yang terpelajar. Indikasinya terungkap pada ungkapan Marshall G. S. Hodgson berikut:

Despite the objections of scholars like al-Biruni, who clung to Arabic, Persian came to be a preferred language (even though the rulers themselves used Turkish); it was in keeping with the Gaznavi tradition that later in India Persian very nearly eclipsed Arabic except in the realm of Shar'i religious scholarship. ${ }^{7}$

(Meskipun terdapat keberatan-keberatan dari para sarjana seperti al-Biruni yang teguh memegang tradisi Arab, bahasa Persia tetap menjadi sebuah bahasa yang dominan digunakan (walaupun sultansultan mereka berasal dari bangsa Turki); Tradisi Persia terpelihara eksistensinya dengan tradisi Gaznawi yang kemudian hari di dalam kebudayaan bangsa India Persia hampir melebihi kebudayaan Arab kecuali dalam bidang syariat agama)

istilah scholar yang terungkap pada kutipan tersebut berarti 'sarjana', 'pelajar' dan scholarship yang berarti ilmu pengetahuan, kesarjanaan. ${ }^{8}$ Karena itu, secara analisis kebahasaan, penulis berpendapat bahwa pada masa pemerintahan Mahmud, penyelenggaraan pendidikan telah berlangsung dan merupakan kelanjutan dari pemerintahan Daulah sebelumnya yakni Abbassiyah. Baik Firdawsi maupun Abu Raihan al-Biruni dapat dikatakan sebagai sarjana-sarjana dari lembaga pendidikan di masa Daulah Gaznawiyah yang beraliran Syiah.

\section{B. Perkembangan Pendidikan pada Masa Daulah Buwaikhi}

Daulah Buwaikhi didirikan pada tahun 945 M $(330$ H) oleh Ahmad ibn Buwaikhi (Buyah). Daulah ini berkuasa di ibukota Bani Abbas sampai tahun $1055 \mathrm{M}(447 \mathrm{H}) \cdot{ }^{9}$ Menurut keterangan Dr. Hamka bahwa Buyah mempunyai tiga orang anak yaitu Ali yang bergelar Imad al-Daulah, Hasan yang bergelar Rukn al-Daulah, dan Ahmad yang bergelar Muiz al-Daulah. ${ }^{10}$

\footnotetext{
${ }^{6}$ Lihat J.J. Sounders, A History of Medieval Islam (London: Routledge and Kegan Paul, 1980), 144; Lihat Marshall G.S. Hodgson, The Venture of Islam-The Expansion of Islam in the Middle Periods (Chicago and London: The Uviversity of Chicago Press, 1974), 41.

${ }^{7}$ Marshall G.S. Hodgson, The Venture of Islam-The Expansion of Islam in the Middle Periods, 41. 1987), 504.

${ }^{8}$ John M. Echols and Hassan Shadily, Kamus Inggris-Indonesia, 15th ed. (Jakarta: PT Gramedia,

${ }^{9}$ Harun Nasution, Teologi Islam : Aliran-Aliran Sejarah (Analisa Perbandingan) (Jakarta: UI Press, 1972), 73; D.S. Margoliouth and et.al, History of Islamic Civilization (New Delhi: Kalan Mahal Daryaganj, 1981), 241.

${ }^{10}$ Hamka, Sejarah Umat Islam, 3rd ed. (Jakarta: Bulan Bintang, 1981), 25-26.
}

Al Qalam: Jurnal Ilmiah Keagamaan dan Kemasyarakatan Vol. 16, No. 2

Maret - April 2022 
Norliani : Pendidikan Masa Daulah Gaznawiyah, Buwaikhi, dan Salajikah (Perkembangan dan Tokohnya)

Pada masa Daulah Buwaikh, gerakan penyebaran paham Syi'ah gencar dilakukan dalam rangka menghilangkan pengaruh Daulah Abbassiyah pada wilayah-wilayah yang dikuasainya. Karena itu penyelenggaraan pendidikan pada masa daulah ini sangat dipengaruhi oleh gerakan tersebut, antara lain mendirikan sekolah-sekolah teologi yang dibangun dengan tujuan tidak hanya digunakan untuk mengadakan perdebatan serius dengan aliran Sunni, khususnya al-'Asy'ariah, tetapi juga merupakan senjata yang ampuh untuk melawan ahli-ahli filsafat Yunani dan orang-orang yang meragukan kebenaran ajaran Islam. Disamping itu, didirikan pula sekolah Mu'tazilah di Bagdad oleh Abu Husain al-Khayyat, Ba Hashimiy oleh Abu Hashim al-Jubba’i dan Ikhshidyyah oleh Ahmad bin 'Ali bin al-Ikhsidi. ${ }^{11}$ Para pemuka Mu'tazilah ini mendirikan sekolah-sekolah tersebut bertujuan untuk mencetak sarjana yang intelek dalam membendung serangan-serangan para filosof Yunani dengan argumentasi yang rasional. ${ }^{12}$ Tujuan tersebut ditetapkan mengingat kemajuan peradaban umat Islam di masa daulah Abbassiyah adalah implikasi dari pengaruh filsafat Yunani yang mendorong transmisi ilmu pengetahuan.

Sedangkan penyelenggaraan pendidikan yang bertujuan melestarikan ajaran Syi'ah, dijumpai pada sekolah yang didirikan di Rayy dan mempunyai cabang di Basrah dan Bagdad. Tujuannya adalah untuk mencetak guru-guru dari Syi'ah Zai'iddiyah. ${ }^{13}$

Dari penyelenggaraan pendidikan pada masa daulah Buwaikhi, politik kekuasaan mendominasi orientasi pendidikan pada setiap sekolah yang didirikannya. Hal ini terlihat dari materi-materi pengajaran yang berpahamkan Syi'ah atau pun paham yang sepaham ${ }^{14}$ dengannya seperti paham aliran Mu'tazilah.

\section{Perkembangan Pendidikan pada Masa Daulah Salajikah}

Setelah masa pemerintahan Daulah Gaznawiyah berakhir, kontrol wilayah kekuasaannya diambil alih oleh Daulah Salajikah. ${ }^{15}$ Dinasti ini pernah berkuasa pada abad XI dan XIII (429-590 H / 1038-1194 M). Nama Dinasti Salajikah atau bani Saljuk ini diambil dari nama pemimpin suku Turki Oghus yang bernama Saljuk bin Tuqaq yang menempati Imperium Ulghar. Sedangkan

${ }^{11}$ Joel L. Kraemers, Renaissance of Islam (Leiden: R. J. Brill, 1989), 72.

12 Joel L. Kraemers, 72.

${ }^{13}$ Joel L. Kraemers, 73.

14 Terdapat persamaan doktrin antara aliran Mu'tazilah dan ajaran Syi'ah, antara lain: doktrin keadilan Tuhan dan kebebasan kehendak manusia yang menjadi Rukun Iman, baik Muktazilah maupun Syi'ah. Walaupun dijumpai muslim yang beraliran Mu'tazilah namun menganut ajaran ahli Sunnah. Harun Nasution, Filsafat Dan Mistisisme Dalam Islam, 33.

${ }^{15}$ Marshall G.S. Hodgson, The Venture of Islam-The Expansion of Islam in the Middle Periods, 41.

Al Qalam: Jurnal Ilmiah Keagamaan dan Kemasyarakatan Vol. 16, No. 2

Maret - April 2022 
Norliani : Pendidikan Masa Daulah Gaznawiyah, Buwaikhi, dan Salajikah (Perkembangan dan Tokohnya)

peletak dasar berdirinya dinasti ini adalah Tughril Beq bin Mikail, cucu dari Saljuk bin Tuqaq. Dinasti Salajikah pernah mengalami masa kejayaan ketika dipegang tiga sultan besar, yaitu : Tughril Beq (1037-1063 M) yang bergelar Ruknuddin Abu Talib, Alp Arselan (1063-1075 M) yang bergelar Idduddin Abu Syuja, dan Malik Syah (1073-1092 M) yang bergelar Jalaluddin Abul Fatah. ${ }^{16}$

Pengembangan pendidikan baru dapat dilakukan pada masa pemerintahan Alp Arselan dan Malik Syah, karena pada masa pemerintahan Tughril Beq disibukkan dalam upaya mempertahankan keutuhan wilayah menguasai kembali wilayah-wilayah kekuasaan yang sempat tercerai berai pada akhir daulah Buwaikh.

Pada masa Alp Arselan, telah dibangun mesjid di Samarkand dan dua Mahligai yang besar. Salah satu dari mahligai tersebut dijadikan tempat penyelenggaraan pendidikan, selain mesjid. Ia pun telah memperbanyak bangunan mesjid di desa dan di kota. ${ }^{17}$ Mengenai sistem pendidikan dan pengajarannya, tidak banyak sejarah yang mengungkapkannya.

Pada masa pemerintahan Malik Syah, melalui menterinya yang bernama Nizam al-Mulk mendirikan Lembaga Perguruan Tinggi Islam terkenal di Baghdad yaitu al-Madras $\pm t$ al-Niz \pm miy $\pm t$ dan "Hanafie School". Ia juga mendirikan observatorium, di tempat inilah Umar Khayyam bekerja. $^{18}$

Pada tiap-tiap kota, Nizam al-Mulk mendirikan satu madrasah yang besar. Di antaranya di Baghdad, Balkh, Naisabur, Herat, Ashfahan, Basrah, Marw, Mousul, dan lain-lain. Bahkan pada tiap-tiap kota di seluruh Irak dan Khurasan ada satu madrasah. Tetapi madrasah yang berada di Bagdad adalah yang terbesar dan terpenting dari semua madrasah itu. ${ }^{19}$ Sedangkan tujuan Nizam al-Mulk mendirikan madrasah-madrasah itu ialah untuk memperkuat pemerintahan Turki Saljuq dan untuk menyiarkan mazhab ke-agamaan pemerintahan. Sultan-sultan Turki itu adalah dari golongan sunni, sedangkan pemerintahan Buwaikh yang sebelumnya adalah dari kaum Syi'ah. Karena itulah madrasah-madrasah Nizamiah didirikan untuk menyokong Sultan dan menyiarkan mazhab sunni ke seluruh rakyat. ${ }^{20}$

\footnotetext{
16 Ahmad Syalabi, Sejarah Dan Kebudayaan Islam, trans. Muhammad Labib Ahmad (Jakarta, Indonesia: Pustaka al-Husna, 1993), 343.

${ }^{17}$ Depag RI, Ensiklopedi Islam (Jakarta: Proyek Peningkatan Prasarana dan Sarana Perguruan Tinggi Agama IAIN, 1992), 1026.

${ }^{18}$ Hasan Ibrahim Hasan, Sejarah Kebudayaan Islam, 253.

${ }^{19}$ Mahmud Yunus, Sejarah Peradaban Islam, 5th ed. (Jakarta: PT. Hidakarya Agung, 1989), 72.

${ }^{20}$ Mahmud Yunus, 72.
}

Al Qalam: Jurnal Ilmiah Keagamaan dan Kemasyarakatan Vol. 16, No. 2

Maret - April 2022 
Norliani : Pendidikan Masa Daulah Gaznawiyah, Buwaikhi, dan Salajikah (Perkembangan dan Tokohnya)

Madrasah Nizamiah ini mulai dibangun pada tahun 457 H (1065 M) dan selesai dibangun pada tahun $459 \mathrm{H}$. Madrasah itu tetap hidup sampai pertengahan abad keempat belas masehi. Jadi madrasah Nizamiah Baghdad itu hidup selama tiga abad lamanya. Adapun guru-guru yang pernah berkiprah di Madrasah Nizamiah Bagdad antara lain: Abu Is¥aq al-Syirazi (wafat 476 H/1083 M), Abu Najr al-cabbagh (477 H/1084 M), Abu al-Qasim al-‘Alawi (482 H/1089 M), Abu Abdullah alThabari (495 H/1101 M0, Abu Hamid al-Gazali (505 H/1111 M), Radliyuddin al-Qazwaini (575 H/1179 M), dan akhir sekali al-Firuzabadi $\left(817\right.$ H/1414 M). ${ }^{21}$ Sebagian besar guru-guru tersebut merupakan alumni dari Madrasah Nizamiyah. ${ }^{22}$

Rencana pengajarannya tidak diketahui dengan tegas. Namun para sejarawan menyimpulkan bahwa Madrasah Nizamiah adalah Fakultas Agama dan Fakultas Syari'ah dan tiada memasukkan ilmu filsafat seperti pada Baitul Hikmah masa dahulu. Kesimpulan ini berdasarkan fakta-fakta sejarah berikut:

1. Tak ada seorang pun di antara ahli sejarah yang mengatakan bahwa di antara mata pelajaran-nya terdapat ilmu kedokteran, ilmu Falak dan ilmu-ilmu pasti. Hanya mereka menyebutkan, bahwa di antara mata pelajaran-nya ialah Nahwu, Ilmu Kalam dan Fiqh.

2. Guru-guru yang mengajar di Madrasah Nizamiah itu adalah ulama-ulama Syari'ah, seperti Abu Ishaq al-Syirazi, al-Gazali, al-Qazwaini, Ibnu al-Jauzi dan lain-lain. Dan tiada dijumpai adanya seorang guru filsafat.

3. Tujuan didirikannya Madrasah Nizamiah bukanlah untuk membela ilmu filsafat, dan bukan pula yang mendukung pembebasan filsafat.

4. Zaman berdirinya Madrasah Nizamiah bukanlah zaman filsafat, melainkan zaman yang justru menindas filsafat dan para filosof. ${ }^{23}$

Analisa Sejarawan memperkirakan bahwa di madrasah Nizamiah diajarkan ilmu fiqh dalam empat mazhab. Buktinya, bahwa di antara gurunya adalah Ibnu al-Jauzi, salah seorang kepala mazhab Hanbali. Tetapi mazhab Syafi'i mempunyai kedudukan istimewa. ${ }^{24}$ Hal ini dapat dimaklumi, karena golongan sunni mayoritas bermazhabkan mazhab Syafi'i.

${ }^{21}$ Mahmud Yunus, 74; Lihat Ahmad Syalabi, Sejarah Dan Kebudayaan Islam, 293; Lihat Philip K. Hitti, History of the Arabs (London: Macmillan, 1970), 411.

${ }^{22}$ Berkat jasa Malik Syah dan Nizam al-Mulk, banyak dilahirkan sarjana-sarjana terkemuka, antara lain : al-Ghazali dengan ilmu Kalam, Imam Fakhrurrazi dan Zamakhsari dengan ilmu Tafsir, dan al-Qusyairu dalam ilmu Tasawuf. Dalam bidang sastra dijumpai Umar Khayyam Ahmad Syalabi, Sejarah Dan Kebudayaan Islam, 293.

${ }^{23}$ Mahmud Yunus, Sejarah Peradaban Islam, 75.

${ }^{24}$ Mahmud Yunus, 75.

Al Qalam: Jurnal Ilmiah Keagamaan dan Kemasyarakatan Vol. 16, No. 2

Maret - April 2022 
Norliani : Pendidikan Masa Daulah Gaznawiyah, Buwaikhi, dan Salajikah (Perkembangan dan Tokohnya)

\section{KESIMPULAN}

Ada empat hal yang dapat disimpulkan dari perkembangan pendidikan pada masa Dualah Gaznawiyah, Buwaikhi dan Salajikah, yaitu:

A. Penyelenggaraan pendidikan terus berkembang menjelang keruntuhan Daulah Abbassiyah, seperti pada masa dualah Gaznawiyah, Buwaikhi dan Salajikah.

B. Politik kekuasaan mempengaruhi model lembaga pendidikan yang berkembang seperti terbentuknya sekolah-sekolah yang berorientasi kemazhaban maupun paham tertentu, dan semua itu tidak terlepas dari aliran atau paham yang dianut oleh sang penguasa seperti pada masa daulah Gaznawiyah dan Buwaikhi dengan paham syi'i.

C. Meskipun pengaruh paham aliran maupun paham mazhab sedemikian kuat dalam pembentukan lembaga pendidikan, namun model madrasah yang dikembangkan oleh Nizam al-Mulk pada masa Daulah Salajikah memberikan kontribusi yang besar pada perkembangan pendidikan masa selanjutnya terutama pembangunan Lembaga Perguruan Tinggi Islam.

D. Tokoh-tokoh yang menopang terselenggaranya pendidikan pada masa Dualah Gaznawiyah, Buwaikhi dan Salajikah yaitu para penguasa dan para ulama/cendekiawan muslim. Sebagian besar dari tokoh-tokoh tersebut merupakan out put / alumni dari lembaga-lembaga pendidikan yang berkembang pada masa dualah tersebut.

\section{DAFTAR PUSTAKA}

Ahmad Syalabi. Sejarah Dan Kebudayaan Islam. Translated by Muhammad Labib Ahmad. 3 vols. Jakarta, Indonesia: Pustaka al-Husna, 1993.

Badri Yatim. Sejarah Peradaban Islam. 2nd ed. Jakarta: PT RajaGrafindo Persada, 1994.

C. Brockelmann. History of Islamic Peoples. London: Routledge and Kegan Paul, 1980.

Depag RI. Ensiklopedi Islam. Jakarta: Proyek Peningkatan Prasarana dan Sarana Perguruan Tinggi Agama IAIN, 1992.

D.S. Margoliouth and et.al. History of Islamic Civilization. New Delhi: Kalan Mahal Daryaganj, 1981.

Hamka. Sejarah Umat Islam. 3rd ed. Jakarta: Bulan Bintang, 1981.

Harun Nasution. Filsafat Dan Mistisisme Dalam Islam. 8th ed. Jakarta: Bulan Bintang, 1992.

—. Teologi Islam : Aliran-Aliran Sejarah (Analisa Perbandingan). Jakarta: UI Press, 1972.

Hasan Ibrahim Hasan. Islamic History and Culture. Translated by Djahdan Umam. 1st ed. Yogyakarta: Kota Kembang, 1989.

Al Qalam: Jurnal Ilmiah Keagamaan dan Kemasyarakatan Vol. 16, No. 2

Maret - April 2022 
Norliani : Pendidikan Masa Daulah Gaznawiyah, Buwaikhi, dan Salajikah (Perkembangan dan Tokohnya)

J.J. Sounders. A History of Medieval Islam. London: Routledge and Kegan Paul, 1980.

Joel L. Kraemers. Renaissance of Islam. Leiden: R. J. Brill, 1989.

Joesouf Sou’yb. Sejarah Daulat Abbassiyah. 2 vols. Jakarta: Bulan Bintang, 1977.

John M. Echols and Hassan Shadily. Kamus Inggris-Indonesia. 15th ed. Jakarta: PT Gramedia, 1987.

Mahmud Yunus. Sejarah Peradaban Islam. 5th ed. Jakarta: PT. Hidakarya Agung, 1989.

Marshall G.S. Hodgson. The Venture of Islam-The Expansion of Islam in the Middle Periods. 2 vols. Chicago and London: The Uviversity of Chicago Press, 1974.

Philip K. Hitti. History of the Arabs. London: Macmillan, 1970.

W. Montgomery Watt. Politik Islam Dalam Lintasan Sejarah. Jakarta: P3M, 1988.

Al Qalam: Jurnal Ilmiah Keagamaan dan Kemasyarakatan Vol. 16, No. 2

Maret - April 2022 